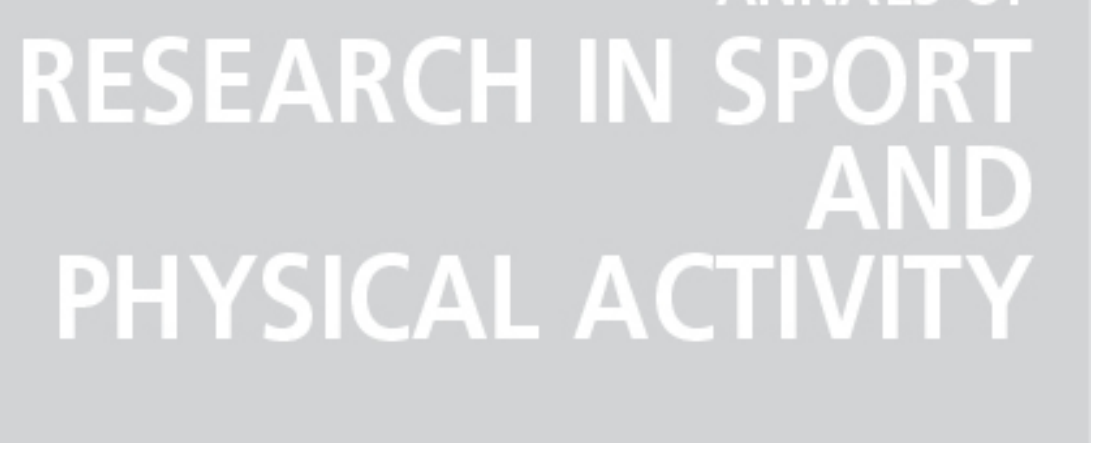

\title{
Active workstations to fight sedentary behaviour: a systematic review
}

Autor(es): $\quad$ Torbeyns, Tine; Meeusen, Romain

Publicado por: Imprensa da Universidade de Coimbra

URL

persistente: URI:http://hdl.handle.net/10316.2/34978

DOI: DOI:http://dx.doi.org/10.14195/2182-7087_5_17

Accessed : $\quad$ 26-Apr-2023 16:22:23

A navegação consulta e descarregamento dos títulos inseridos nas Bibliotecas Digitais UC Digitalis, UC Pombalina e UC Impactum, pressupõem a aceitação plena e sem reservas dos Termos e Condições de Uso destas Bibliotecas Digitais, disponíveis em https://digitalis.uc.pt/pt-pt/termos.

Conforme exposto nos referidos Termos e Condições de Uso, o descarregamento de títulos de acesso restrito requer uma licença válida de autorização devendo o utilizador aceder ao(s) documento(s) a partir de um endereço de IP da instituição detentora da supramencionada licença.

Ao utilizador é apenas permitido o descarregamento para uso pessoal, pelo que o emprego do(s) título(s) descarregado(s) para outro fim, designadamente comercial, carece de autorização do respetivo autor ou editor da obra.

Na medida em que todas as obras da UC Digitalis se encontram protegidas pelo Código do Direito de Autor e Direitos Conexos e demais legislação aplicável, toda a cópia, parcial ou total, deste documento, nos casos em que é legalmente admitida, deverá conter ou fazer-se acompanhar por este aviso. 
(5) 2014

\section{ANNALS OF \\ RESEARCH IN SPORT AND \\ PHYSICAL ACTIVITY}

FACULDADE DE

CIÊNCIAS DO

DESPORTO E

EDUCAÇÃO FÍSICA DA UNIVERSIDADE DE COIMBRA

IMPRENSA

DA UNIVERISDADE

DE COIMBRA :

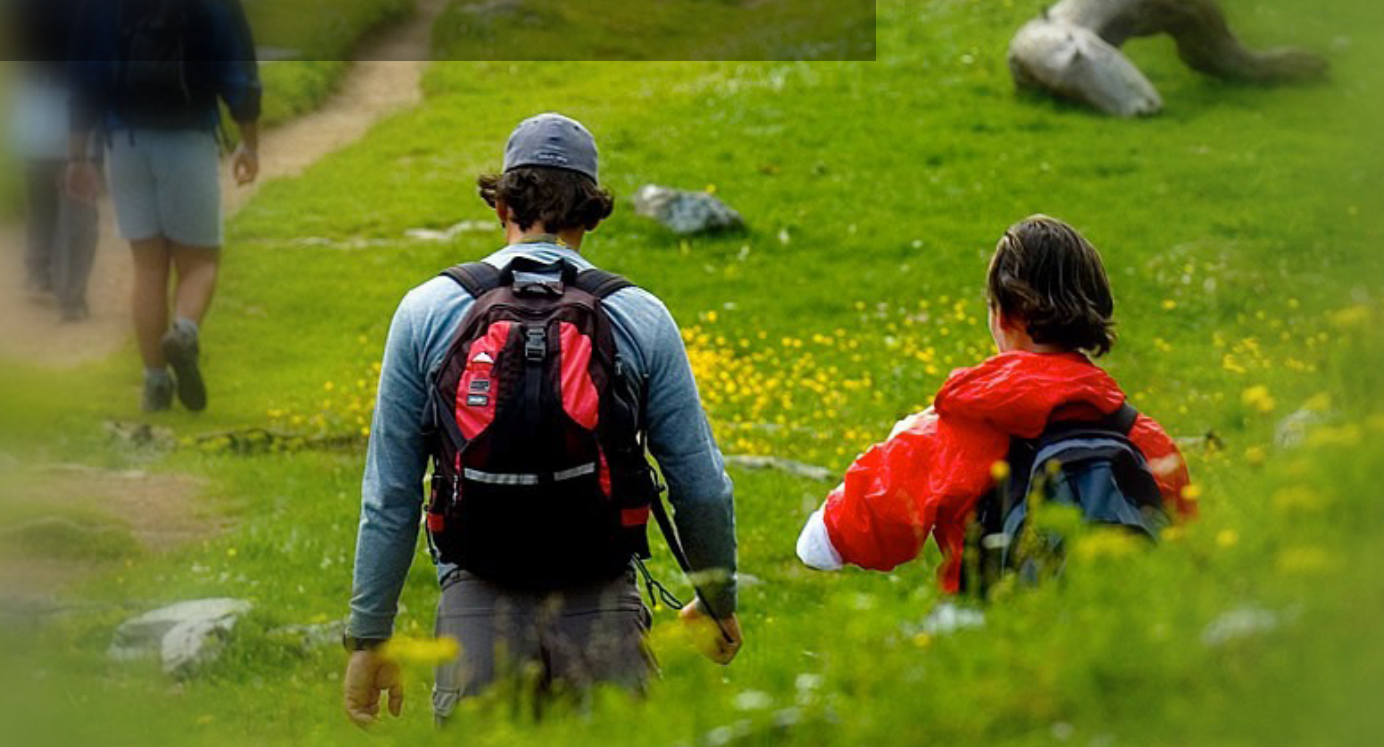



SEDENTARY BEHAVIOUR: A SYSTEMATIC REVIEW 

Tine Torbeyns' ${ }^{1}$ Romain Meeusen ${ }^{1}$

Tine.Torbeyns@vub.ac.be; rmeeusen@vub.ac.be

\section{BACKGROUND:}

The impact of active workstations has been studied in several settings and several outcomes have been investigated. However, the effects on health, work performance, quality of life, etc. have never been systematically reviewed.

\section{OBJECTIVE:}

To evaluate the existing literature about active workstations, and the possible positive health and work performance effects.

\section{DATA SOURCES:}

We searched the electronic databases PubMed and Web of Science (until September 23, 2013). Search terms included active workstation, standing workstation, standing desk, stand up workstation, stand up desk, walking workstation, treadmill workstation, treadmill desk, cycling workstation, bike desk, health, quality of life, cognition, computer performance, absenteeism, productivity, academic achievement, cognitive decline, and independent living. In addition, we searched the reference lists of relevant published articles.

\section{STUDY SELECTION:}

Randomised controlled trials and quasi-experiments, investigating the introduction of active workstations in humans were included. We did not accept studies combining the

\footnotetext{
1 Vrije Universiteit Brussel, Dept Human Physiology
} 
introduction of active workstations with other interventions, nor observational studies. Outcomes concerning health, energy expenditure, cognition, quality of life and work performance were included.

\section{RESULTS:}

We included 29 studies of which 5 longitudinal studies in school-aged children, 9 longitudinal and 15 non-longitudinal studies in adults. Fourteen investigated standing desks, 14 walking desks, and 1 a cycling workstation. General findings are decreased sitting time, increased energy expenditure, a positive effect on several health markers, no detrimental effect on work performance, no acute effect on cognitive function and no straightforward findings concerning computer task performance.

\section{CONCLUSIONS:}

The implementation of active workstations might contribute to improving people's health and physical activity level. The effect of the use of these active workstations on cognition and applied work tasks such as computer task performance needs further investigation before conclusions can be made. Another aspect that needs further investigation is the implementation of the different active workstations in all age-groups. 